\title{
症例報告
}

\section{十二指腸に穿破，出血し緊急脺頭十二指腸切除術を 施行した膵仮性囊胞の 1 例}

\begin{tabular}{|c|c|c|c|c|c|c|}
\hline 津谷 & 康大 & 久保 & 義郎 & 棚田 & 稔 & 柿下 大一 \\
\hline 沖田 & 充司 & 野崎 & 功雄 & 南 & 一仁 & 青儀健二郎 \\
\hline 栗田 & 啓 & 高嶋 & 成光 & & & \\
\hline
\end{tabular}

症例は 27 歳の男性で, 突然の吐血でショック状態となり搬送された．初診時 $\mathrm{Hgb} 3.8 \mathrm{~g} / \mathrm{dl}$ と 高度の貧血を認めた．腹部 CT では膵頭部に約 $5 \mathrm{~cm}$ の囊胞性病変を認め, また膵体部から尾部 にかけ石灰化が存在し，慢性膵炎の像であった，入院中突然の下血を認め，緊急上部消化管内 視鏡検査を施行した。二指腸下行脚は壁外性の圧排を受け，その中心部は壊死に陥り，同部 位より持続性の出血を認めた. 出血のコントロールは困難であり, 緊急で開腹手術を施行した. 術中所見では膵頭部に囊胞性腫瘤を認め，周囲は浮腫状であった．膵仮性囊胞の十二指腸穿破 による出血と診断し，膵頭十二指腸切除術を施行した。病理組織学的検査では膵仮性囊胞であ り主膵管との交通も認めた。術後経過は良好で，第 18 病日に退院した．膵仮性囊胞の消化管へ の穿破はまれであり，特に十二指腸への穿破の報告は少ないが，囊胞が原因となる出血により 急激な経過をたどることもあり，注意が必要と思われた。

\section{はじめに}

膵仮性囊胞は急性, 慢性膵炎の約 10～15\% に生 じる ${ }^{1)}$ そそのうち膵囊胞内出血は約 $10 \%$ に認めら れ，その死亡率は $25 〜 45 \%$ と高率で2), 重篤な合 併症の一つである。今回, 我々は吐下血にて発症 した膵仮性囊胞の十二指腸穿破という極めてまれ な 1 例を経験したので文献的考察を加え報告す る.

\section{症例}

症例 : 27 歳, 男性

主訴：吐血

既往歴：特記事項なし.

生活歴：19歳時より 1 日に缶ビール $350 \mathrm{ml} \mathrm{4,}$ 5 本の飲酒歴を認めた。腹部外傷歴なし.

現病歴：2004 年 2 月, 突然の吐血でショック状 態となり, 救急車で近医に搬送された. Hgb 3.8g/ $\mathrm{dl}$ と高度の貧血を認め, 計 8 単位の濃厚赤血球の

$<2005$ 年 9 月 28 日受理 $>$ 別刷請求先 : 津谷 康大 ₹731-4311 安芸郡坂町北新地 2-3-10 済生会広島 病院外科
輸血を受けた。胃内視鏡検查では胃内には古い血 液のみで潰瘍などの出血源はなく，十二指腸球部 にも出血点は認めなかった。腹部 CT では膵頭部 に約 $5 \mathrm{~cm}$ の囊胞性病変を認め, 精査加療目的にて 当科に紹介入院となった.

入院時現症：身長 $160 \mathrm{~cm}$, 体重 $56 \mathrm{~kg}$. 眼瞼結膜 に軽度の貧血を認めた。腹部は平坦，軟で腫瘤は 触知しなかった。

入院時血液生化学検査 : $\mathrm{Hgb} 8.4 \mathrm{~g} / \mathrm{dl}$ の貧血を 認めた。その他特記事項はなく, 腫瘍マーカー CEA, CA19-9 も正常範囲内であった(Table 1).

上腹部 $\mathrm{CT}$ : 膵頭部に約 $5 \mathrm{~cm}$ 大の境界明瞭な 囊胞性腫瘤を認めた (Fig. 1a)．膵頭部から膵尾部 には点状の石灰化が散在しており, 慢性膵炎に伴 う膵仮性囊胞が考えられた（Fig. 1b).

入院中突然，大量の下血を認め，同日上部消化 管内視鏡検査を施行した。十二指腸下行脚は壁外 性の圧排を受け，その中心部は壊死に陥り，同部 位より持続性の出血を認めた (Fig. 2). 出血のコ ントロールは困難であり, またショック状態と 
Table 1 Laboratory data on admission

\begin{tabular}{lc|lc}
\hline WBC & $56 \times 10^{2} / \mu \mathrm{l}$ & T-Bil & $0.6 \mathrm{mg} / \mathrm{dl}$ \\
$\mathrm{RBC}$ & $341 \times 10^{4} / \mu \mathrm{l}$ & D-Bil & $0.2 \mathrm{mg} / \mathrm{dl}$ \\
$\mathrm{Hgb}$ & $8.4 \mathrm{~g} / \mathrm{dl}$ & Tcho & $111 \mathrm{mg} / \mathrm{dl}$ \\
$\mathrm{Ht}$ & $29.1 \%$ & $\mathrm{TP}$ & $6.2 \mathrm{~g} / \mathrm{dl}$ \\
$\mathrm{PLT}$ & $39.8 \times 10^{4} / \mu \mathrm{l}$ & $\mathrm{Alb}$ & $3.7 \mathrm{~g} / \mathrm{dl}$ \\
& & $\mathrm{BUN}$ & $6.5 \mathrm{mg} / \mathrm{dl}$ \\
$\mathrm{GOT}$ & $38 \mathrm{IU} / l$ & $\mathrm{Cr}$ & $0.68 \mathrm{mg} / \mathrm{dl}$ \\
$\mathrm{GPT}$ & $41 \mathrm{IU} / l$ & $\mathrm{P}-\mathrm{AMY}$ & $74 \mathrm{IU} / l$ \\
$\mathrm{LDH}$ & $245 \mathrm{IU} / l$ & S-AMY & $105 \mathrm{IU} / l$ \\
$\gamma$-GTP & $51 \mathrm{IU} / l$ & FBS & $79 \mathrm{mg} / \mathrm{dl}$ \\
$\mathrm{ChE}$ & $0.41 \Delta \mathrm{pH}$ & & \\
$\mathrm{LAP}$ & $59 \mathrm{IU} / l$ & $\mathrm{CEA}$ & $0.9 \mathrm{ng} / \mathrm{ml}$ \\
$\mathrm{ALP}$ & $182 \mathrm{IU} / l$ & CA19-9 & $0.9 \mathrm{U} / \mathrm{ml}$ \\
\hline
\end{tabular}

なったため, 緊急で開腹手術を施行した.

術中所見：膵頭部に約 $5 \mathrm{~cm}$ の囊胞性腫瘤を認 め, 周囲は浮腫状であった (Fig. 3). 膵仮性囊胞 の十二指腸穿破による出血と判断し, 膵頭十二指 腸切除術を施行した. 再建は Child 法で行った。

切除標本 : 膵頭部に約 $5 \mathrm{~cm}$ 大の囊胞性腫瘤を 認め, 内部は凝血槐で充満していた (Fig. 4a).

囊胞は十二指腸下行脚に穿破しており，この部で 十二指腸の壁は壊死に陥っていた（Fig. 4b).

病理組織学的検査: 膵仮性囊胞であり, 主膵管 との交通を認めた。 また, 囊胞壁は比較的太い静 脈と交通を認めた (Fig. 5). 悪性所見は認めなかっ た。

術後濃厚赤血球を計 5 単位輸血したが, 経過は 良好で第 18 病日に退院した。

\section{考察}

膵仮性囊胞の自然経過としては，7〜20\% が合 併症を来すことなく自然消失するとされている が， 7 週以上経過観察しても消失しない場合はそ れ以降は破裂, 感染, 膿瘍形成, 出血などの合併 症が増えるのみといわれている3).

膵仮性囊胞内出血の機序としては, (1)囊胞内圧 の上昇による囊胞壁の壊死のため表在血管から出 血する ${ }^{4)}$, (2)膵臓の炎症性病変が脾動脈, 胃十二指 腸動脈などに仮性動脈瘤を形成し，これが破綻し 出血する ${ }^{5}$, (3)仮性囊胞が膵管や胃などと瘻孔を形 成し消化液が逆流して膵蛋白分解酵素が活性化さ れ, 囊胞壁の血管にびらんを生じて出血する場合6)
が挙げられる，本症例では，病理組織学的に主要 動脈からの出血は明らかではなく, 囊胞と交通す る比較的太い静脈を認めたことより(2)は否定的 で, (1), (3)の両機序が混在したものが考えやすい. 膵仮性囊胞内出血の出血形態には, (1)囊胞内の みの出血, (2)腹腔内への穿破, (3)近接消化管への 穿破, (4)胆管への穿破, (5)主膵管経由で十二指腸 乳頭部からの出血がある7). 本症例は(3)に該当す る. (5)の病態は Hemosuccus pancreaticus と命名 されている ${ }^{5}$. 本症例は内視鏡的に十二指腸乳頭部 からの出血は確認されてはいないが, 病理学的に 囊胞と主膵管との交通を認めていた。また，初発 時 $\mathrm{Hgb} 3.8 \mathrm{~g} / \mathrm{dl}$ と高度の貧血を認めたことより, それ以前から慢性的な出血が存在していたことが 推測され, 十二指腸へ穿破する以前に Hemosuccus pancreaticus を合併していたことも否定でき ない.

本邦における膵仮性囊胞の消化管穿破の報告 は, 1975 年から 2004 年の医学中央雑誌(会議録を 除く）で「膵仮性囊胞」をキーワードに検索した かぎりでは，計 19 例であった，平均年齢は 49.4 歳(34〜 74 歳), 全例男性であった. 穿破部位は胃 12 例, 大腸 5 例, 空腸 (輸入脚) 1 例, 胃および 十二指腸 1 例であり, 好発穿破部位は胃であった. 発生部位は 18 例が膵体尾部であり, 膵頭部発生の ものは 1 例であった。 十二指腸への穿破例は 1 例 報告されているが, この症例はまず動脈塞栓術を 施行し, 3 日後の再出血に対し再度塞栓術を施行 し, さらにその後胃穿破による囊胞壁からの出血 に対しクリッピングによる止血術を行い, その後 6 か月の時点で再発は認めていない8).

膵仮性囊胞の出血時の治療法としては, 理想的 には囊胞を含めた外科的切除であるが, 近年では 経カテーテル的動脈塞栓術（transcatheter arterial embolization : 以下, TAE と略記) などの interventional radiology (以下, IVR と略記)による 止血も試みられている。 この疾患は本来良性でも あり，より非侵襲的な治療が選択される傾向にあ $ろ^{9) \sim 11)}$. TAEの成功率は 66-100\% と報告されて

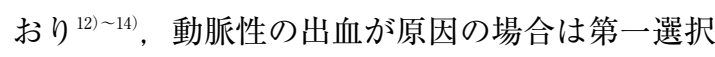
と考えられる. しかしながら, TAE 施行後の再出 
Fig. 1 a : CT showed a cystic tumor $5 \mathrm{~cm}$ in diameter on the pancreas head. $\mathrm{b}$ : There were calcifications from the pancreatic body to tail.
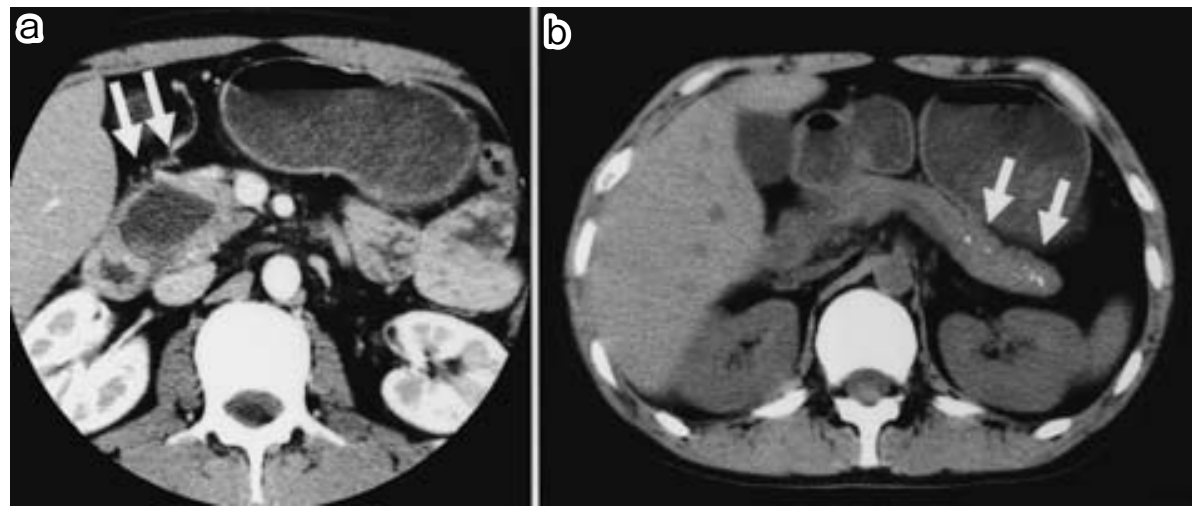

Fig. 2 Gastrointestinal fiberscopy showed a submucosal tumor on the second portion of the duodenum and active bleeding from the center of the tumor.

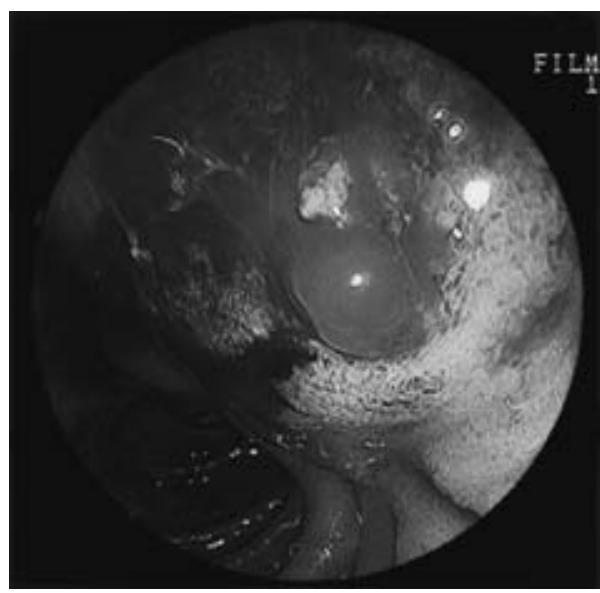

血は $37 \%$ と高く ${ }^{14)}$, 一時的な止血には有効である が，後に外科的手術が必要となる場合も多いよう である．囊胞残存，膵炎の悪化，また消化管穿破 を起こした場合は穿破部位の残存の問題もあり，

TAE 施行後は入念な経過観察が必要であると思 われる。本症例においてもまず血管造影により出 血点を確認した後 TAE を施行するという選択肢 も考えられたがショック状態となりより緊急性が あったこと, 術前の内視鏡検査で囊胞が十二指腸 に穿破し，非動脈性の出血を認めていたこと，ま た若年であり緊急手術に耐えうると判断したため
Fig. 3 Operative findings showed a cystic tumor on the pancreatic head.

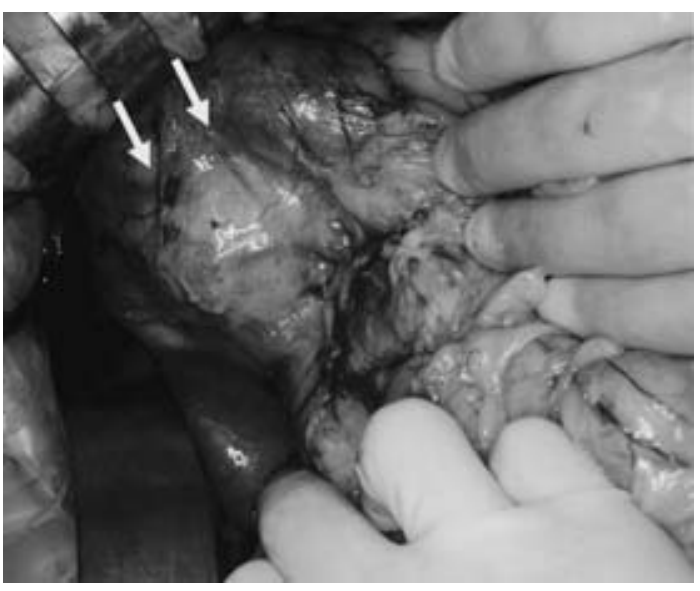

開腹手術を選択した. 膵頭十二指腸切除という侵 襲の大きな手術を要したが, 囊胞の完全切除が行 われ, 再出血の可能性はないと考えられる. また, 本来なら幽門輪温存膵頭十二指腸切除術の適応で はあるが，緊急手術のため，手技が慣れ，合併症 も少ない膵頭十二指腸切除術 (Child 再建) を行っ た．本症例では血管造影は行っていないが，病理 学的に囊胞壁と太い静脈に交通を認め, 明らかな 動脈の破綻は認めなかったことより, TAEを施行 した場合の止血効果の有無は不明である、膵頭部 の囊胞を切除した場合の死亡率は $43 \%$ という報 
Fig. 4 a : Surgical specimens revealed a cystic tumor $5 \mathrm{~cm}$ in diameter on the pancreatic head and coagulated blood in the tumor. $\mathrm{b}$ : The tumor fenestrated into the duodenum and the duodenum was necrosed.
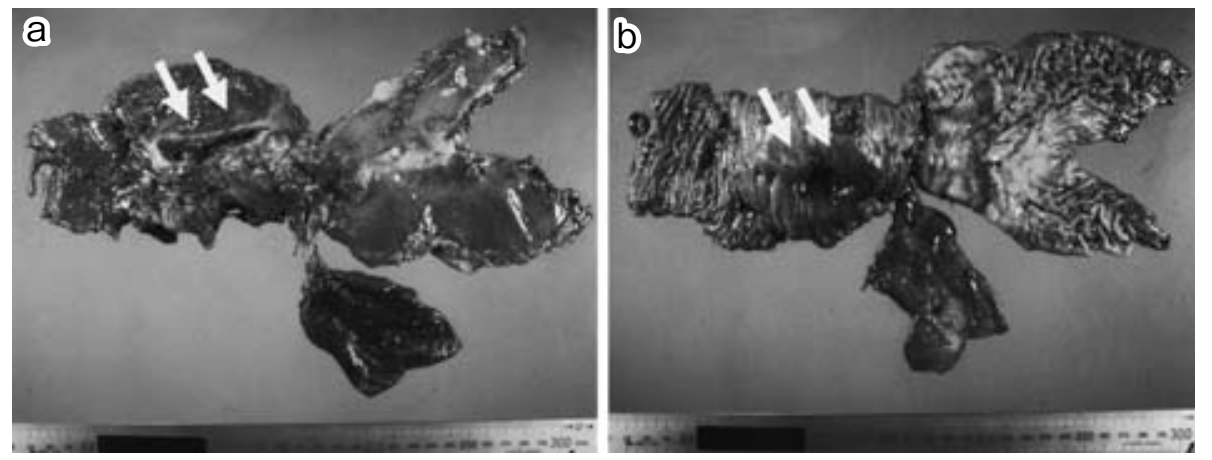

Fig. 5 A large vein was connected with the cyst wall.

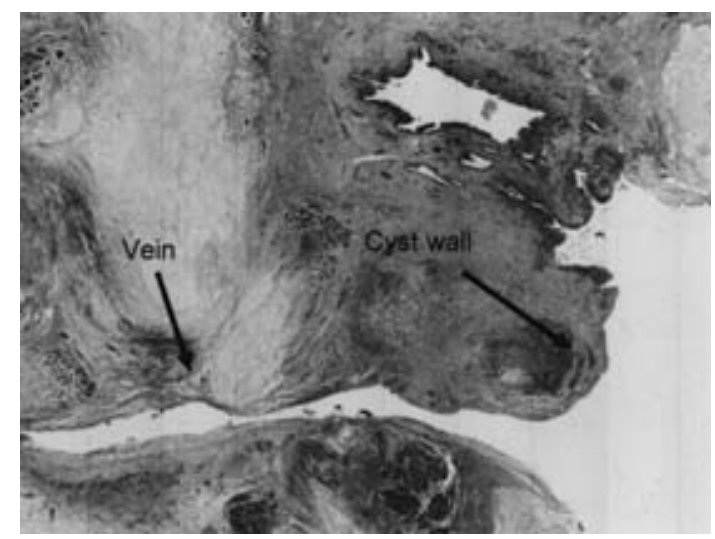

告もあり ${ }^{215)}$ ，手術適応には慎重を要するが，IVR 無効例や IVR による効果が期待できない症例に 関しては切除の適応があると考える.

本病態は消化管出血の一因として常に念頭に入 れておくべきである．近年では TAEなど IVR による止血の報告もあるが，根治的な意味では常 に外科的手術も考慮し, 個々の症例に応じて慎重 に治療方針を決定していく必要があると思われ た.

\section{文献}

1) Simpson A, Srivastava VK : Pseudocyst of pancreas. Br J Surg $60: 45-49,1973$
2) Stabile BE, Wilson SE, Debas HT et al : Reduced mortality from bleeding pseudocysts and pseudosneurysms caused by pancreatitis. Arch Surg $118: 45-51,1983$

3) Bradley EL, Clemennts JL, Gonzales AC : The natural history of pancreatic pseudocysts ; a unified concept of management. Am J Surg 137 : 135-141, 1979

4) Dardik I, Dardik H : Patterns of hemorrhage into pancreatic pseudocysts. Am J Surg 115 : 774776, 1968

5) Sandblom $P$ : Gastrointestinal hemorrhage through the pancreatic duct. Am J Surg 171 : $61-66,1970$

6) Greenstein A, DeMario EF, Nabseth DC : Acute hemorrhage associated with pancreatic pseudocyst. Surgery $69: 56-62,1971$

7）佐藤 力, 遠藤 剛, 土屋豊一ほか: 十二指腸乳 頭部より上部消化管出血をきたした偽動脈瘤を 伴う仮性膵囊胞内出血の 1 例. 胆と膵 6 : 1421-1426, 1985

8）佐藤佳宏, 斎藤拓朗, 土屋貴男ほか：十二指腸お よび胃へ穿破した膵仮性囊胞内出血の一例. 福島 医誌 $54: 101-108,2004$

9) Dias JA, Gutierres MG, Torres-Meelero J et al : Embolization of the gastroduodenal artery for the treatment of massive hemorrhage in a patient with chronic pancreatitis. Eur J Surg 160 : 393395,1994

10）齋藤 真, 蓮見桂三, 峯 徹哉: 膵仮性囊胞に対 して経カテーテル的動脈塞栓術 (TAE) が有効で あった 1 例. 膵臓 $18: 29-34,2003$

11）中村友則, 石田 淳, 吉儀 淳ほか: 胃穿通をき たした膵仮性囊胞内出血に動脈塞栓術を施行し た 1 例. 臨放線 48:945一948, 2003

12) Perrot MD, Berney T, Buhler L et al : Manage- 
ment of bleeding pseudoaneurysms in patient with pancreatitis. Br J Surg 86 : 28-32, 1999

13) Beattie GC, Handman JG, Redhead D et al : Evidence for a central role for selective mesenteric angiography in the management of the major vascular complications of pancreatitis. Am J Surg $185: 96-102,2003$

14) Boudghene F, L'Hermine C, Bigot JM : Arterial complications of pancreatitis : diagnostic and therapeutic aspects in 104 cases. J Vasc Interv Radiol 4 : 551-558, 1993

15) Marshall GT, Howell DA, Hansen BL et al : Multidisciplinary approach to pseudoaneurysms complicating pancreatic pseudocysts. Arch Surg $131: 278-283,1996$

\title{
Emergent Pancreaticoduodenectomy for the Hemorrhagic Pancreatic Pseudocyst Fenestrating into the Duodenum : A Case Report
}

\author{
Yasuhiro Tsutani, Yoshiro Kubo, Minoru Tanada, Tomokazu Kakishita, \\ Atsushi Okita, Isao Nozaki, Kazuhito Minami, Kenjiro Aogi, \\ Akira Kurita and Shigemitsu Takashima \\ Department of Surgery, National Hospital Organization Shikoku Cancer Center
}

A 27-year-old man admitted for hematemesis with anemia was found in CT to have a 5-cm cystic mass in the pancreatic head and scattered calcification from pancreatic body to tail. Gastrointestinal fiberscopy showed a submucosal tumor in the second portion of the duodenum and active bleeding from the tumor center. Based on a diagnosis of pancreatic pseudocyst fenestration into the duodenum, we conducted emergency pancreaticoduodenectomy. Histopathologically, the tumor was diagnosed as a pancreatic pseudocyst fenestrating into the duodenum and connected to the main pancreatic duct. The postoperative course was uneventful and the man was discharged on postoperative day 18. Pancreatic pseudocysts fenestrating into the gastrointestinal organs is rare, especially into the duodenum.

Key words : pancreatic pseudocyst, gastrointestinal bleeding, pancreaticoduodenectomy

[Jpn J Gastroenterol Surg $39: 232-236,2006$ ]

Reprint requests : Yasuhiro Tsutani Department of Surgery, Saiseikai Hiroshima Hospital 2-3-10 Kitashinchi, Saka-cho, Aki-gun, 731-4311 JAPAN

Accepted : September 28, 2005 